APITOIIG

$\mathrm{B}^{\wedge} \mathrm{G} A \mathrm{AC}, \mathrm{IIIG}$, GURJUI, IERUII.G, IANG

D...terocar us 5.

Family: Dipterocar acea.

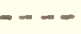

By

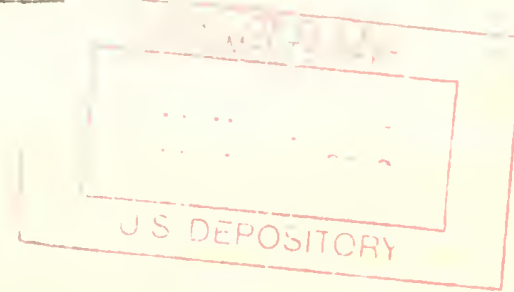

ELOIST-GMRI, Forest Products Mecinologist Division of Silvicultural Relations

In the areas where it occurs, the Dipterocarp family, with $1 y$ genera and nearly 400 species, rills the place in timier rocuction that is occu ied by soitroods, oaks, and other fariliar species in the liorti Temperate zone.

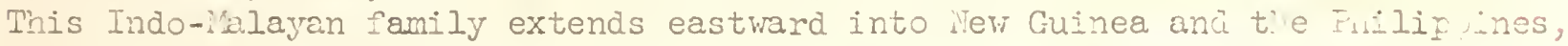
and tro geneja occur to the west in the Sejchelles Islands and n trojical Arica (2I). The Dipterocarps are made $u_{-}$mainly of species tiat are noted for producing very large trees, often in nearlir jure stanas (Q).

The genus Dipterocarpus, to winch ajtonf belongs, includes aivout 70 sjecies of large trees. Fleven are round in Incia, 5 in Ceylon, 15 in ti.e lininine Islands where tiey rate as the most abundant structural timber, 14 or more in Borneo ( 12$)$, and some 30 otiers in tie iblay Feninsula and t e Indian Archipelago (4, 5, 14, 21, 31).

Iinintained at Vadison, i'is., in cooperation witi the University of Wisconsin. - Underlined numbers in parentieses refer to the list of numered references at the end of the articie. 
Apitong, as lnown commercially, may be the product of not less than 15 species of tie genus Dipterocarjus (I). The most comon species are D. grandiflorus Blanco ( $=$ D. tuberculatus Rox. $), D$. lasiopodus Perlins, and D. vernicifluus Blanco (I, I7).

In adition to apitong, which is a comion nane in the Philipines, a number of other trade and vernacular names are orten applied to these roods. These include eng in India and England (2, 21), gurjun in Burma, lreruing in the Malay Peninsula, hora in Ceylon, and Jang in Siar (4 $4,5,34$ ).

\section{The Tree}

Dipterocarpus grandiflorus Blanco ( $=$ D. tuberculatus Roxb.) may be considered as a typical species of the group of woods called apitong. It is one of the most generally known and widely distributed.

$\underline{\text { Size }}$

The trees may attain a height of 50 to 135 feet, often with 50 to 90 feet of clear, straight, cylindrical bole before the first branches. Girths of 8 to 15 feet and diameters $u_{p}$ to 90 inches have jeen reported. The trees have comparatively sinall buttresses (1, ㄴ, 2, 14, 21).

Leaves

The deciduous (ㅇ) leaves are leathery and smooth (30).

Flowers

The fragrant flowers are white or pink in color (31).

Fruit

The fruit is one-celled with two large outwardly curved wings (3I).

Barl:

The bark may be 3 to 4 inches thick, brittle, and light gray to dark browish gray. It sheds off in large scroll-shaped plates and bears many corky pustules; the inner bark is reddish. Resin used for varnish, torches, and boat caulking erudes when the $1 / 2-i n c h$ inner bark is cut. The ends of tile logs tend to be resinous and "tacky" (노 2, 14, 31). 
The roods of the different species called ajitong are so similar tinat it is

dificult to distinguish one sjecies from another (26).

\section{Color}

The savrood, $3 / 4$ to 3 or more inches in thicliness, maj be tro-zoned; the outer zone may have a crearny-yellor, gray, or reddisi-white color that shades into reddisi-purple or brom $(4,5)$. The sapwood tones into tize darker redöisi-or purplish-irown heartwood, which darkens on exposure (4, $2,14,15$, 21).

Grain, Texture, and Figure

Apitong wood may notably have fairly straight grain, but it may also be shallorly interlocied or cross grained. Its even texture is fine to ratier coarse (나, 2, 10, 14, 21, 26, 34).

\section{Luster}

Apitong is not a lustrous wood (15, 26).

Odor and Taste

The wood has a slightly pleasant resinous odor but no distinct taste (11, 14, 15, 26).

\section{Weiglit}

The weight of apitong, depending on its moisture content, ranges from 36 to 66 pounds per cublc foot viti a usual range of 40 to 57 pounds (4, 2, 2, 12, 13, 21, 26).

Specific Gravity values from 0.60 to 0.86 have been reported (1, 14, 15, 21, 26).

\section{Mechanical Properties}

Strength values of apitong determined on material from different localities in the Philippines varied considerably. The strongest wood was that with the highest density (I, I). Test data from some early Philippine tests (6) have been taiulated in tab̄le 1 , wich lists values for some properties of green and 
Table 1.--Physical and strength properties of green and air-dry apitong from the Philippines

\section{Property}

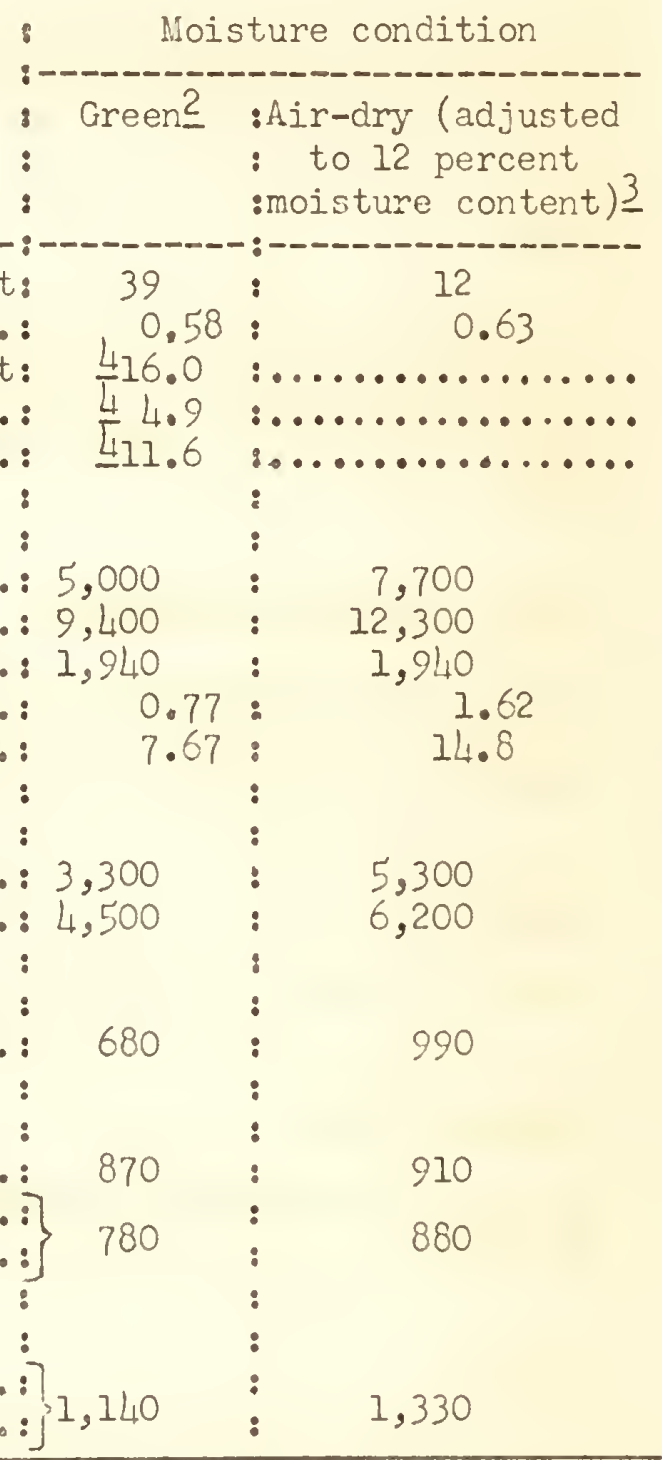

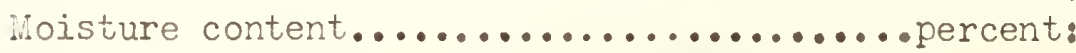
Specific gravity -- volume as tested.............. Shrinkage, in volume -- green to oven-dry..percent: Shrinkage, radial -- green to oven-dry..........do.: Shrinlage, tangential -- green to oven-dry.....do.:

Static bending

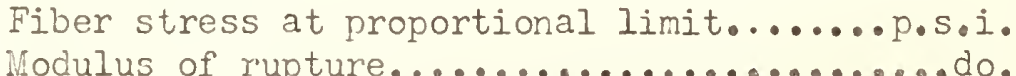

Modulus of elasticity................,000 p.s.i.:

Work to proportional limit...in.-lb. per cu. in.:

Work to maximum load.....................do.

Compression parallel to grain

Crushing strength at proportional limit...p.s.i.

Maximum crushing strength.................do.

Compression perpendicular to grain

Crushing strength at proportional limit.......do.

Hardness ${ }^{\prime}$

End................................ b.

Radial............................... do.:

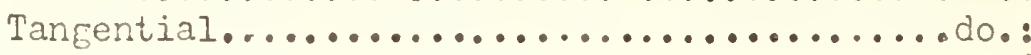

Shearing strength

Radial...................................

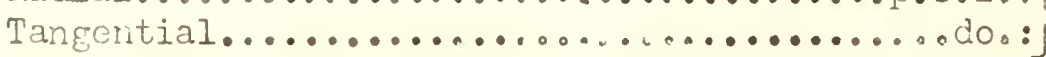

ITable nrepared by John T. Drow, Timber Mechanics Division, U. S. Forest Products Laboratory.

2Data on green material from "Comparative Strength Properties of the Principal Philippine Commercial Moods," by Jose C. Espinosa, Phil. Jour. Sci. Vol. 33, No. L, 1927.

3 Data on air-dry material from same source as data for green material but acjustec from 17 to 12 percent moisture content on the basis of t?e usual exprential relationship, assuming an "intersection point" of 25 percent moisturc content.

IShrinkage data are approximate, representing the sum of shrinkage values from green to air-dry and air-dry to oven-dry, as reported in Phil. Bur. For. Tech. Bull. No. 7, Appendix 6.

ILoad to imbed a 0.444 -inch steel ball to $1 / 2$ its diameter. 
air-diry material. These data were obtained from specimens of tive sizes used for Forest Products Laboratory tests. They have ieen converted from metric system units and adjusted to 12 percent moisture content to make them comarable to deta available on familiar United States species. Other test data from Indic, lalara, and the Plilinines have Deen reported elsevhere but are based on syecimens of different sizes with different moisture content values or are in different units (10, 13, 21, 26, 29).

\section{Seasoning and Shrinkage}

Comrehensive seasoning information is not avallable for ajitong. The range of variation in density and resin content of the material sold in vorld marlets as apitong is considerable. It is believed, however, that with the careful use of modem drying methods ajitone can be adequately seasoned, in site of the fact that it nas had a reputation for being slow to dry and sonewht refractory with notable tendencies to wary, check, silit, anö colla, se (4, 2, 21). Air seasoning (ㄹ) or air seasoning prior to kiln arying nave botil jeen used with tisis material.

The British Forest Products Research Iaboratory has recommendicd relatively mild treatment for avitong, starting with temperatures of $110^{\circ}$ or $120^{\circ} \mathrm{F}$. and 85 percent relative ilumidity (Schedules Nos, $\overline{4}$ and 5, Leaflet iNo. 42, "Iiz In Drying Schedules," 1949). The U. S. Forest Products Laboratory in its 1951 "Schedules for the Kiln Drving of Vood" (Forest Products Laboratory dieport No. DI791) lists as a generally applicable mild schedule, Tj-ul, wich has been suggested for use with green apitong. Sciedule T5-C2 in this report vould proviaje a more severe schedule if conditions apjeareà to varrant it.

As an efiective general procedure for minimizing warping, a sticler sacing of not over 18 inches, with all stickers in vertical alinement, ana weighting dom of the top of the pile has been used.

Shrinlage figures recorded (26) for apitong are:

$$
\frac{\text { Radial }}{\text { (Percent) }} \frac{\text { Tangential }}{\text { (Percent) }} \frac{\text { Longitudinal }}{\text { (Percent) }} \frac{\text { Volumetric }}{\text { (Percent) }}
$$

Green to air-dry

Air-dwy to oven-dry

$\begin{array}{ll}2.3 & 6.7 \\ 2.6 & 4.9\end{array}$

0.1
0.1
3.6
7.4

\section{Workaidity}

Worling characteristics vary considerably among the different species of Dipterocarpus and even witin the same species, as influenced by growth conditions. The woods are senerally consicered as moderately difficult to work. The presence of silica (4, 5) ana gun ray give some trouile from blunting of cutting edges or clowing of savs (3, 4, 2, 34). A. Gooa finish and polisi, however, can be ovteined, especinlly in tiroroushy dried material (14, 21). Ixceptionally resinous material is troublesome, for example, in 
floorins (4, 5), and in the tropics some staining and corrosion have veen reportec where the wood was in contact with iron $(\underline{4}, 5)$.

\section{Durability}

Dipterocarpus species are rated as only moderately durable in exposed positions (34). For example, untreated railway ties in Inaia lasted only 4 to 5 years and house josts only about 1 year (2I). lloods from these species serve well for interior work, but need preservative treatment if used in contact with the ground. They absorb preservatives readily, however, even with open-tank treatment $(\underline{4}, 5,14)$. The heartwood of apitong has been reported as resistant to dry-wood termites and powder post beetles (2I).

\section{Dềects}

Heart checlss or sinales, oil sialses, end splits, and surface checlss sometimes occur or develop during seasoning of apitong (4, 5). Except for the fact that the sapwood is not decay resistant and is attacked by beetles (12), these woods are comparatively free from defects in the logs. The logs, however, should be removed from the woods as soon as possible after the trees are felled. Resin sometimes exudes over the surface of sawn material and a dulling effect on the cutting edges of woodworking tools has been noted (12).

\section{Uses}

Apitong is used in construction where hard and heavy timber is required. Its uses include "posts above sturms," beams, joists, rafters, partitions, flooring, mine props, bridges and wharves, poles and railway ties (with preservative treatment), wagon beds, auiomobile Iraraing, framing of barges and lighters, boats, carts, boxes, railroad cars, and medium-grade furniture $(2, \underline{21}, \underline{26})$.

\section{Availability}

Apitong is reported as one of the most abundant structural timbers found in good sizes in the Philippines. Volumes of 1,000 to 14,000 board feet per acre have been reported (35).

\section{Structure}

Growth rings are not distinct. Pores tend to be rather evenly distributed, rounded in shape, open, and somewhat isolated, Rays are of two sizes (2) but appear to be few in number and narrow. Resin ducts are diffusely scattered and surrounded by bands of parenchyma (14, 26). 


\section{Minor Products}

Consicierable quantities of oleoresin (minjak leruing) are contained in tle wood. Tre resin may exude over tine ends of logs and is sometimes collectea in hollows hacked in tlee tree trunks. It is used for ceulleing boats and cor medicine (12). 
1. Aguilar, Luis

1939. The Mechanical Properties of Apitong from Tayabas Province and Negros and Basilan Islands. Phil. Jour. For. Vol. 2, No. 2, pp. $145-157$.

2. Asiddao, $F$.

1938. Air-drying Rate of One- and Two-inch Apitong Boards Under Open Shed. Phil. Jour. For. Vol. 1, No. 3, pp. 283-291.

3. Clarke, S. H.

1937. Gurjun, Apitong, Keruing, Kapur and Allied Timbers. Forest

Products Research Records No. 16 (Timber Series Nio. 5), pp. 11,

$1 \mathrm{pl}$. London. (Rev. Tropical Toods No. 51, p. 30.) (Rev. by Arthur Koehler, Jour. For. Vol. 37, No. 4, p. 353, 1939.)

4. Desch, H. E.

1941. Dipterocarp Timbers of the Malay Peninsula. Nalayan Forest Records No. 14, pp. 62-75, illus.

5.

194l. Manual of Malayan Timbers. Malayan Forest Records Vol. 1, No. 15, pp. 101-108.

6. Espinosa, Jose C.

1927. Comparative Strength Properties of the Principal Commercial Toods of the Philippines. Phil. Jour. Sci. Vol. 33, No. 4, pn. $381-395$.

7.

1928. Strengt1 Properties in Relation to Specific Gravity of Philippine Woods. Phil. Jour. Sci. Vol. 36, No. 1, pr. 55-69.

8. Foxworthy, F.W.

1927. Commercial Timber Trees of the Malay Peninsula. Malayan Forest Records No. 3, pp. 43-44. Singapore.

9. Gamble, J. S.

1922. A Manual of Indian Timbers. 2nd. ed., pp. 70, 72. Sampson Low, Marston \& Co., Ltd. London.

10. Gardner, Rollan

1906. Mechanical Tests, Properties and Uses of Thirty Philippine Voods. Philippine Bur. For. Tech. Bull. No. 4 (Manila).

11. Howard, A. L.

1948. A Manual of the Timbers of the World. 3rd ed., pp. 30-3.1, $174-175,196-200,291,648$. Macmilian Co. 
12. Keith, H. G.

1947. Timbers of North Bnrneo. Pr. 29-33. Hong Kong.

13. Kent, H. T. M.

1920. Report on the Results of Mechanical Tests Carried Out on Some Malayan Timbers. Conservator of Forests, Kuala Luinpur.

14. Kraemer, J. Hugo

1951. Trees of the ". "estern Pacific Region. Pp. 275-277. Tri-State Offset Co., Cincinnati, Ohio.

15. Kribs, D. A.

1950. Comercial Foreign Woods on the American Narket. P. 68 (illus.) School of Forcstry, Pennsylvania State College.

16. Lamb, George N.

1950. Dipterocarpaceae. Wood Products Vol. 55, No. 2, p. 36.

17. Merriji, E. D.

1923. Enumeration of Philippine Flowering Plants. Vol. 3, fp. 88-91.

18.

1926. Bibliography of Philippine Botany. Enumeration of Plilippine Flowe ring Plants. Vol. L, pn. 155-239.

19.

1945. Plant Life in the Pacific World. Pp. 80-81. Macmillan Co.

20. Metcalfe, C. R. and Chalk, L.

1950. Anatomy of the Dicotyledons. Pp. 212-220. Clarendon Press, Oxford, England.

21. Pearson, R. S. and Rrom, H. P.

1932. Commercial Timbers of India. Vols. I and 2, pp. 67-70, 81-85, illus. (Nany refs.) Gort. of India, Calcutta.

22. Reinking, A. O. and Humphrey, C. J.

1931. Laboratory Tests on the Durability of Philippine Woods Against Fungi. Phil. Jour. Sci. Vol. 15, No. 1, pp. 77-89. (Rer. Tropical Woods No. 27, p. LI.)

23. Reyes, Luis i.

1923. Woods of the Philippine Dipterocarps. Phil. Jour. Sci. Vol. 22, No. 3, pp. 291-3Li (32I-322).

24.

1930. Apitong (Dinterocarpus spp.) of Northern Negros. Nakiling Echo (Nanila) Vol.9, No. I, pp. 37-39. (Rev. Tropical Toods No. 22, pr. 14-16.) 
25.

1930. Characteristic Figure in Philippine Woods. Timberman (Portland, Oreg.) Vol. 31, No. 12, pp. 99-100, illus. (Rev. Tropical Woods No. 25, p. 30.)

26.

1938. Philippine Woods. Philippine Bur. For. Tech. Bull. No. 7 (Manila), pp. 34, 280-286, 288-296, 454, 457, 467, 470, 480.

27. and Aguilar, Luis

1934. Properties and Uses of Common Philippine Woods. Makiling Echo (Manila) Vol. 13, No. 3, pp. 139-174. (Rev. Tropical Woods No. 40, p. 52.)

28. Salvoza, F. M. and Lagrimas, Martin

1940. Check List of the Trees of the Philippines With Brief Notes on Their Uses. Phil. Jour. For. Vol. 3, No. 4, pp. 477-547, 4th Quart.

29. Schneider, E. E.

1916. Commercial Woods of the Philippines. Their Preparation and Uses. Philippine Bur. For. Tech. Buil. No. 14 (Manila), pp. 163-164.

30. Scott, C. W.

1932. Tests in the Rangoon River on the Damage by Marine Borers to Various Woods, Including Burma Teak and British Guiana Greenheart, Creosoted and Untreated. Burma Forest Bull. No. 28 (Econ. Ser. No. 5) Rangoon, pp. 10, illus. (Rev. Tropical Woods No. 30, p. 52.)

31. Symington, C. E.

1941. Foresters' Manual of Dipterocarps. Malayan Forest Records, No. 16, pp. 153-166, 178-180. Kuala Lumpur.

32. Tamesis, Florencio

1927. Annual Report of the Director of Forestry of the Philippine Islands for the Fiscal Year Ended December 31, 1926. Pp. 292. Manila. (Rev. Tropical Woods No. 14, p. 45.)

33. Thomas, A. V.

1934. Result of Mechanical and Physical Tests on Fully Air-dried Timbers. Malay Forester Vol. 3, pp. 15-17.

34. Timber Development Asso., Itd.

Some Commerciel Timbers of Malaya. Timber Information Ref. No. 38 .

35. Whitford, H. W.

1911. The Forests of the Philippines. Forest Types and Products. Philippine Bur. For. Tech. Bull. No. 10 (Manila). 